\title{
Heart ventricles specific stress-induced changes in $\beta$-adrenoceptors and muscarinic receptors
}

\author{
Andrej Tillinger ${ }^{1}$, Martina Novakova ${ }^{2}$, Olga Krizanova ${ }^{3}$, Richard Kvetnansky ${ }^{1}$ and Jaromir \\ Myslivecek $^{2}$ \\ ${ }^{1}$ Institute of Experimental Endocrinology, Centre of Excellence CENDO, Slovak Academy of Sciences, Vlarska 3, 83306 \\ Bratislava, Slovak Republic \\ ${ }^{2}$ Institute of Physiology, $1^{\text {st }}$ Faculty of Medicine, Charles University, Albertov 5, 12800 Prague, Czech Republic \\ ${ }^{3}$ Institute of Molecular Physiology and Genetics, Centre of Excellence for Cardiovascular Research, Slovak Academy of Sciences, \\ Vlarska 5, 83334 Bratislava, Slovak Republic
}

\begin{abstract}
The left and right ventricles fulfill different role in heart function. Here we compare chamber specific changes in local catecholamine concentrations; gene expression and the receptor protein amount of all three $\beta$-adrenoceptors ( $\beta$-AR) in rat right heart ventricles exposed to acute ( 1 session) and repeated (7 sessions) immobilization stress (IMMO) vs. previously observed changes in left ventricles. Density of muscarinic receptors as main cardio-inhibitive receptors was also measured. In the right ventricles, noradrenaline and adrenaline were increased. No $\beta_{1}$-AR changes were observed, in spite of the increased sympathetic activity. On the other hand, we have found a decrease of $\beta_{2^{-}}$ AR gene expression (reduction to 30\%) after 7 IMMO and protein (to 59\%) after 1 IMMO. $\beta_{3}$-AR gene expression was increased after 7 IMMO. Muscarinic receptor density was not changed. When comparing correlation in left and right ventricles, there was strong correlation between adrenaline and $\beta_{2}$-AR gene expression, protein and $\beta_{3}$-AR gene expression in the left ventricles while only correlation between adrenaline and $\beta_{2}$-AR mRNA and protein in the right ventricles was found. Our results show that maintenance of cardiac homeostasis under stress conditions are to a great extent achieved by a balance between different receptors and also by a balanced receptor changes in left $v s$. right ventricles. Taken together, decrease of cardio-stimulating $\beta_{2}$-AR represents a new important mechanism by which $\beta_{2}$-AR contributes to the heart physiology.
\end{abstract}

Key words: Beta-adrenergic receptors - Binding sites - Catecholamines - Gene expression - Heart - Stress

\section{Introduction}

The function of the heart is regulated via sympathetic and parasympathetic nerves. The effects of respective neurotransmitters (i.e. adrenaline/noradrenaline and acetylcholine) are mediated via almost antagonistic G-protein-coupled receptors: adrenoceptors and muscarinic receptors (Burnstock 2009). In the heart, the main subtypes of receptors that mediate parasympathetic action are $\mathrm{M}_{2}$ muscarinic receptors (Gomeza et al.

Correspondence to: Jaromir Myslivecek, Institute of Physiology, $1^{\text {st }}$ Faculty of Medicine, Charles University, Albertov 5, 12800 Prague, Czech Republic

E-mail: jmys@lf1.cuni.cz
1999; Burnstock 2009). As there is need for the homeostatic balance between sympathetic and parasympathetic nerve tonus, there is also need of balance between the amount of muscarinic receptors $(\mathrm{MR})$ and $\beta$-adrenoceptors $(\beta-\mathrm{AR})$ as well as the functional output of these receptors. These premises have been proved repeatedly (Myslivecek et al. 1996; Garofolo et al. 2002; Brodde and Leineweber 2004; Stavrakis et al. 2011).

Physiological effects of catecholamines in the heart are mediated mainly via $\beta$-AR (Brodde and Michel 1999; Brodde et al. 2006). $\beta_{1}$-AR are the predominant subtypes expressed in the heart and their stimulation produces positive inotropic and chronotropic effects. In addition to this adrenoceptor subtype, $\beta_{2}$-AR are also expressed in the heart with partly similar function as $\beta_{1}-\mathrm{AR}$, i.e. they are cardio-stimulative (Bernstein 
et al. 2011) but with important differences in pathological circumstances like heart failure (Bernstein et al. 2011).

All $\beta$-AR are members of the G-protein-coupled receptor family. $\beta_{1}$-AR and $\beta_{2}$-AR couples to $G_{s}$ proteins, stimulates adenylyl cyclase (AC), which subsequently leads to increase in cAMP intracellular levels. The sufficiency of cAMP is the key point in activation of protein kinase A (PKA), which phosphorylates also the L-type $\mathrm{Ca}^{2+}$ channels and thus promotes calcium influx and enhances cardiomyocytes contraction. Accumulated evidence indicates that, at least in the rat and murine hearts, stimulation of $\beta_{1}$-AR causes not only positive inotropic and chronotropic effect, but can also promote apoptosis of cardiomyocytes (Xiao et al. 2006). Persistent $\beta_{1}$-AR stimulation changes the receptor signaling pathway from PKA to $\mathrm{Ca}^{2+} /$ calmodulin-dependent protein kinase II predominance, leading to myocyte maladaptive remodeling (Xiao et al. 2006). On the other hand, prolonged $\beta_{2}$-AR activation switches the receptor G-protein coupling from $G_{S}$ to $G_{i}$ and thereby possesses antiapoptotic effect resulting in cardioprotection (Communal et al. 1999; Xiao et al. 2006).

On the other hand, the role of $\beta_{3}-A R$ in the heart remains controversial and contradictory data were published. Shortly, different expression/role/function was found in specific heart chambers (i.e. in atria and ventricles (Brixius et al. 2004; Spasojevic et al. 2011) and in different species (Gauthier et al. 2000; Skeberdis et al. 2008)). Some authors found the $\beta_{3^{-}}$ AR to be antagonistic to $\beta_{1}$ - and $\beta_{2}$-AR (Rozec and Gauthier $2006)$ - following prolonged activation by the sympathetic nervous system, the $\beta_{3}$-adrenergic response is preserved, while the $\beta_{1}$ - and $\beta_{2}$-adrenergic responses are diminished; some authors found that $\beta_{3}$-AR increase contractility (Skeberdis et al.2008) but this can be also the question of different heart chambers. Moreover, metabolic effects were also demonstrated for $\beta_{3}-A R$ (Arch and Wilson 1996), these effects are mediated via different pathways (cAMP-dependent pathway, NO-cGMP-mediated pathway, activation of ion channels and many others), what also enlarge the functional consequences of $\beta_{3}$-AR activation. Importantly, some authors also claimed no $\beta_{3}$-AR agonist-induced effects in the heart (Molenaar et al. 1997; Kaumann and Molenaar 2008).

In the heart, the coupling of $\beta_{3}$-AR is proposed to be coupled to the $G_{i}$ protein. In human ventricles activation of $\mathrm{G}_{\mathrm{i}}$ proteins causes an activation of endothelial $\mathrm{NO}$ (eNOS) synthase (Gauthier 1998; Schulz et al. 2005). The NO production induces an increase in intracellular cyclic guanosine monophosphate (cGMP). Alternatively, NO can act via cGMP-independent way through the modification of cytochrome c oxidase or L-type calcium channel (for review see (Rozec and Gauthier 2006). It's supposed that $\beta_{3}-\mathrm{AR} / \mathrm{NO}$ pathway could act as a negative feedback mechanism opposing the positive inotropic influences of catecholamines in the heart. In full contrast with the other $\beta$-AR subtypes, stimulation of the $\beta_{3}$-AR produced a marked decrease in cardiac contractility in human heart (Rozec and Gauthier 2006). Negative inotropic effects and changes in $\beta_{3}$-AR gene expression were noted in many cases, when $\beta_{3}$-AR agonists were used (Gauthier 1998; Gauthier et al. 1999; Tavernier et al. 2003) . Compared to $\beta_{1}$ - and $\beta_{2}$-AR, the $\beta_{3}$-AR presents a relative in vitro and in vivo lack of desensitization following activation with agonists (Nantel et al. 1993).

Recently, we have shown important changes in $\beta_{3}$-AR and other AR in stress (Laukova et al. 2013). Shortly, the concentration of noradrenaline in the left ventricles decreased while adrenaline increased, especially after repeated immobilization (IMO). The mRNA and protein levels and binding sites of $\beta_{3}$-AR significantly rose following chronic IMO while all parameters for $\beta_{2}$-AR dropped after single as well as repeated exposure. Similarly, the mRNA levels and binding sites for $\beta_{3}$ $\mathrm{AR}$ increased in the left atrium as a consequence of chronic IMO. The rise in $\beta_{3}$-AR and a drop in $\beta_{2}$-AR resulted in inhibition of adenylyl cyclase activity within the left ventricles.

Therefore, this study was focused on the investigation of single and repeated stress effects on mRNA and protein levels of $\beta_{1^{-}}, \beta_{2^{-}}$, and $\beta_{3}-\mathrm{AR}$, as well as on total muscarinic receptor binding sites (as virtually only receptor subtype in the heart is $\mathrm{M}_{2}$ muscarinic receptors) in right cardiac ventricles and on comparison of right/left ventricles stressinduced changes.

\section{Materials and Methods}

\section{Animals and tissue preparation}

Male Sprague-Dawley rats (250-300 g, Charles River, Suzfeld, Germany) were used in our experiments. All experiments were performed in accordance with the Guide for the Care and Use of Laboratory Animals published by the US National Institutes of Health (NIH Publication No. 85-23, revised 1996) and approved by The Ethic Committee of the Institute of Experimental Endocrinology (Slovak Academy of Sciences, Bratislava, Slovakia). Prior to experiments, animals were housed for at least 1 week, four animals per cage in a controlled environment $\left(22 \pm 2^{\circ} \mathrm{C}, 12 \mathrm{~h}\right.$ light/dark cycle, lights on at 6 a.m.). Food and water were available ad libitum. Immobilization stress was performed as described previously (Kvetnansky and Mikulaj 1970): by taping (with adhesive tape) all four legs, in the prone position, to a fixed board. In the process of a single immobilization, rats were restrained once for $2 \mathrm{~h}$ and decapitated $3 \mathrm{~h}$ after the termination of the immobilization stimulus. Repeated stress was achieved by immobilizing animals for the 7 consecutive days ( 2 hours each), with decapitation after the last, seventh immobilization ( $3 \mathrm{~h}$ after the termination of last immobilization). The rats endured the stress procedure well and all survived the seven-fold exposure. All animals were sacrificed without anaesthetic. Heart was rapidly removed, 
ventricles (left and right) separated, and immediately frozen in the liquid nitrogen and stored at $-70^{\circ} \mathrm{C}$ until the assay.

Determination of tissue catecholamines (noradrenaline and adrenaline)

Catecholamine concentration was determined by a modified method of Peuler and Johnson (Peuler and Johnson 1977). Frozen tissues were weighted and immediately homogenized in $0.1 \mathrm{~mol} / \mathrm{l} \mathrm{HClO}_{4}$. Homogenate was centrifuged at 10,000 $\times g$ for $15 \mathrm{~min}$. An aliquot of supernatant was taken and diluted to the final concentration $1 \mathrm{mg}$ of tissue per $50 \mu \mathrm{l}$. Rest of the method was the same as for plasma catecholamine quantification (Peuler and Johnson 1977). Briefly, tritiated neurotransmitter metabolites production was measured using catechol-O-methyl-transferase-catalyzed radioenzymatic assay. The assay was sensitive similarly to the values reported originally by Peuler and Johnson (1977), i.e. 1 pg (20 pg/ml of plasma) for both neurotransmitters.

$R N A$ isolation and relative quantification of $m R N A$ levels by reverse transcription with subsequent polymerase chain reaction ( $R T-P C R)$

Total RNA from frozen heart tissue was isolated by TRI Reagent (MRC Ltd.) according to the manufacturer's instructions. Concentration and purity of RNA was determined spectrophotometrically on a GeneQuant Pro (Amersham Bioscience). PCR specific for adrenoceptors, primers and PCR conditions were carried out as described previously (Myslivecek et al. 2006). Reverse transcription was performed using Ready-To-Go You-Prime First-Strand beads and $\mathrm{pd}(\mathrm{N}) 6$ primer. The initial denaturation was performed at $95^{\circ} \mathrm{C}$ for 5 minutes followed by denaturation and annealing (different temperature and time) and followed by polymerization (at $72^{\circ} \mathrm{C}$ in all cases). The final polymerization lasting 7 minutes was performed at $72^{\circ} \mathrm{C}$ in all cases.

PCR products were analyzed on $2 \%$ agarose gels and visualized using ethidium bromide. Intensity of individual bands $\left(\mathrm{OD} / \mathrm{mm}^{2}\right)$ was evaluated by PCBAS 2.08e software (Raytest, $\mathrm{GmbH}$ ). As a control, the housekeeper glyceraldehyde 3-phosphate dehydrogenase (GAPDH) was used. For semiquantitative evaluation the values were normalized to the signal obtained with GAPDH.

Protein isolation and relative quantification of protein levels by Western blot analysis

Membrane proteins were isolated by modified method described in Barbier et al. (2004). Heart tissue was homogenized in $20 \mathrm{mmol} / \mathrm{l}$ Tris ( $\mathrm{pH} 7.0$ ), $0.3 \mathrm{~mol} / \mathrm{l}$ sucrose and proteases inhibitors cocktail (Pefabloc SC and Complete (EDTA free); ROCHE Diagnostic), then centrifuged for 15 $\min$ at $1000 \times g$ and $4^{\circ} \mathrm{C}$. Supernatant was taken out and centrifuged at $45,000 \times g$ and $4^{\circ} \mathrm{C}$ for $45 \mathrm{~min}$. The pellet was dissolved in homogenization solution, and protein concentration was determined according to Bradford (1976). Western blot analysis was carried out as described previously (Krizanova et al. 2001). Briefly, protein extract from the cardiac ventricles $(50-180 \mathrm{mg})$ was separated by SDS-PAGE and then transferred to a supported nitrocellulose membrane (Hybond-ECL, AP Biotech) using semidry blotting. The membrane was blocked in 5\% nonfat dry milk in Tris-buffered saline-Tween and incubated with the rabbit polyclonal antibody against specific receptors (see below). After the membrane was washed three times, it was incubated in the secondary anti-rabbit antibody conjugated to horseradish peroxidase (dilution 1:5,000). Secondary antibody was visualized by enhanced chemiluminiscence (AP Biotech). Levels of the $\beta_{1^{-}}, \beta_{2^{-}}$and $\beta_{3}$-AR proteins were determined using a specific polyclonal primary antibody (sc568, sc569, sc-1473, all were targeted to C-terminus; Santa Cruz Biotechnology). Every protein was quantified using GAPDH protein as housekeeping gene standard. All protein levels were normalized using GAPDH standard (measured as optical density) which level did not differ between blots for different types of receptors and between experiments. The scatter was less than $10 \%$ in every case.

\section{Radioligand binding experiments}

The tissue sample was weighted and homogenized in ice cold Tris-EDTA buffer (Tris-HCl 50 mmol/l, EDTA 2 mmol/l, pH adjusted to 7.4). Membranes were prepared as was previously reported (Fischer et al. 2008). Amount of muscarinic receptor binding sites was determined as previously reported (Myslivecek et al. 2006), using 65-2000 pmol/1 [ $\left.{ }^{3} \mathrm{H}\right] \mathrm{QNB}$ $\left({ }^{3} \mathrm{H}-( \pm)\right.$-Quinuclidinyl[phenyl-4-3H] benzilate, As = 1.35 $\mathrm{TBq} / \mathrm{mmol})$ ), non-specific binding was determined with $5 \mu \mathrm{mol} / \mathrm{l}$ atropine (incubation for $120 \mathrm{~min}$ at $38^{\circ} \mathrm{C}$ ). All incubation times were adjusted previously (Myslivecek et al. 2006). The amount of binding sites $\left(B_{\max }\right)$ per $\mathrm{mg}$ protein was determined using BCA (bicinchoninic acid) method kit (Sigma) and the affinity constant $\left(\mathrm{K}_{\mathrm{D}}\right)$ was computed by non-linear regression using GraphPad Prism 5.01 program (GraphPad Software). $\mathrm{K}_{\mathrm{D}}$ were used for the "single-point" measurement in order to save the amount of tissue needed, using following saturating concentrations of radioligand $\left(1500 \mathrm{pmol} / \mathrm{l}\left[{ }^{3} \mathrm{H}\right] \mathrm{QNB}\right)$ using the equation as previously (Fischer et al. 2008).

\section{Statistical analysis}

Results are presented as mean \pm S.E.M. and each group represents an average of 6 animals. Statistical differences among groups were determined by one-way or two-way 
ANOVA, and for multiple comparisons an adjusted $t$-test modified by Bonferroni's or SNK (Student-NewmanKeules) correction was used. Subsequently, the values (catecholamine concentration $v s$. mRNA, protein, binding) were plotted against each other. The correlations were analyzed using Pearson's correlation coefficient (r) and the corresponding p-values (using GraphPad software). In all cases, a value of $p<0.05$ was considered as statistically significant.

\section{Results}

Catecholamine levels in right cardiac ventricles of rats exposed to single or repeated immobilization

Noradrenaline concentration significantly increased in repeatedly $(7 \times \mathrm{IMMO})$ stressed rats (Fig. 1A). Adrenaline concentration was much lower compared to noradrenaline. In spite of the low concentration, adrenaline levels were increased in right ventricles of both singly $(1 \times \mathrm{IMMO})$ and repeatedly $(7 \times \mathrm{IMMO})$ stressed rats.

\section{Effect of single and repeated immobilization on $\beta$-AR's gene} expression, and protein levels in right heart ventricles

No significant changes of $\beta_{1}$-AR mRNA levels of singly $(1 \times \mathrm{IMMO})$ or repeatedly $(7 \times \mathrm{IMMO})$ stressed rats were found (Fig. 1B). On the other hand, significant changes were observed in $\beta_{2}$-AR gene expression in repeatedly $(7 \times \mathrm{IMMO})$ stressed rats. Similarly, mRNA levels of $\beta_{3}$-AR were elevated in repeatedly $(7 \times \mathrm{IMMO})$ stressed rats.

Protein levels of $\beta_{1}$-AR were also unchanged in $1 \times$ and $7 \times \mathrm{IMMO}$ rats (Fig. 1C). Protein levels of $\beta_{2}$-AR were found significantly decreased after the single immobilization. Protein levels of $\beta_{3}$-AR were not changed.
A

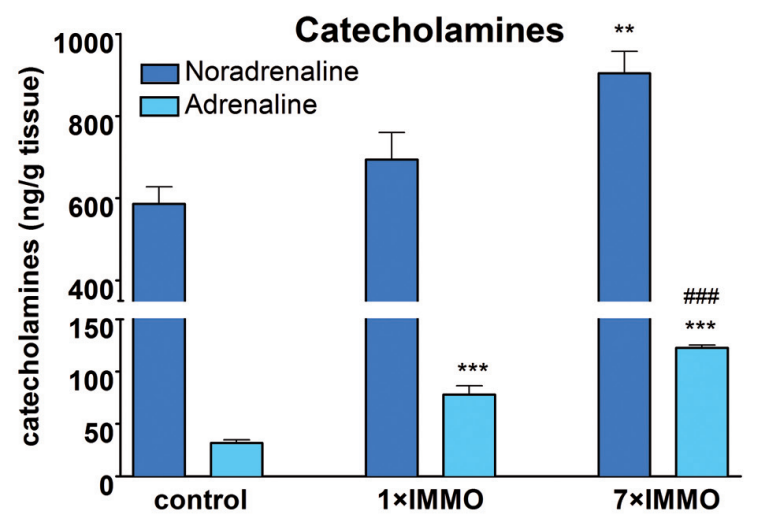

C

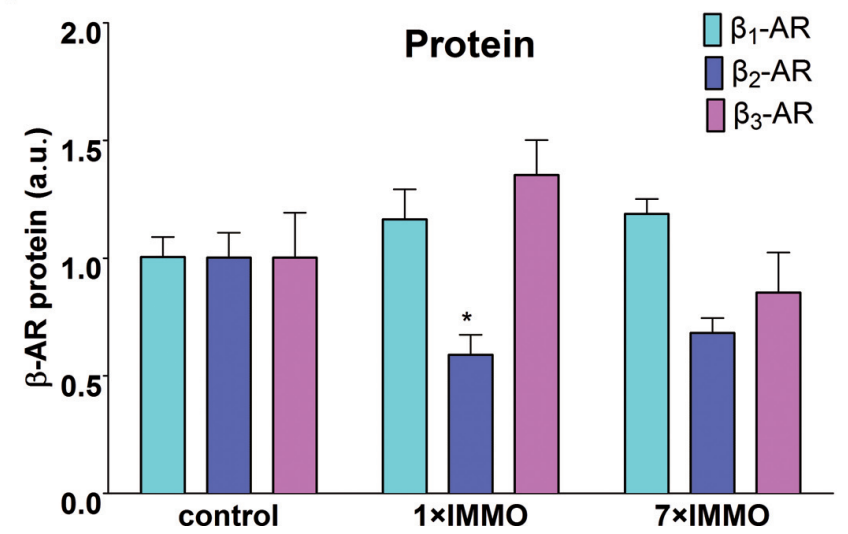

B

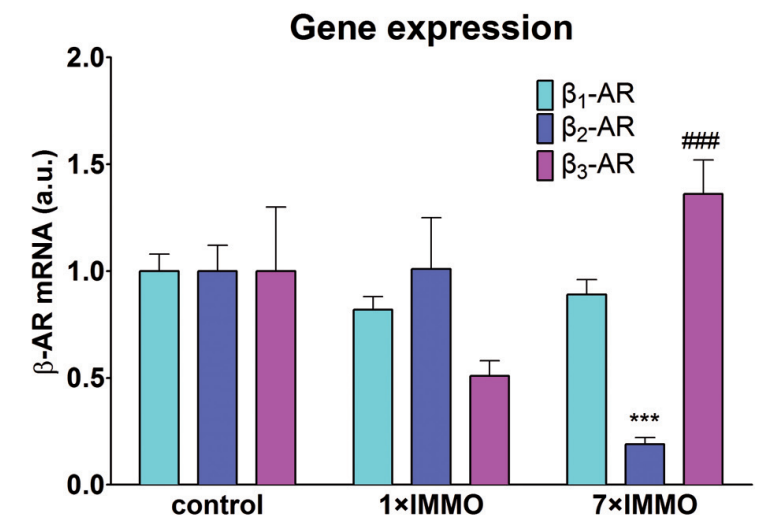

D

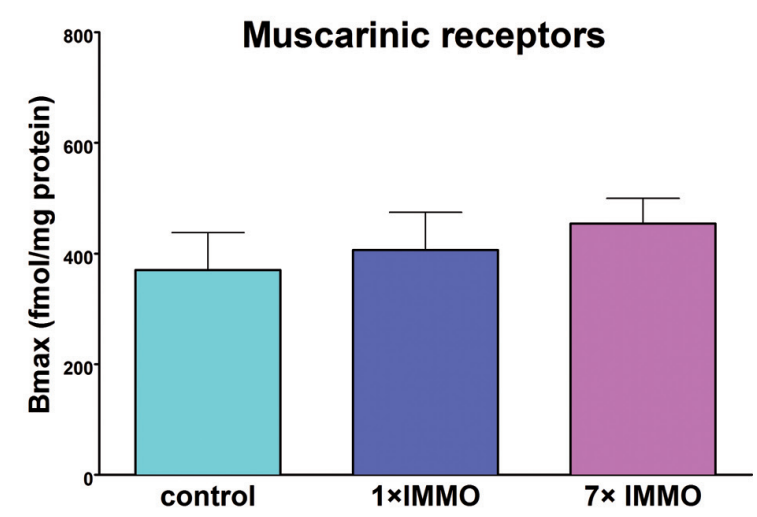

Figure 1. Noradrenaline and adrenaline concentrations (A), changes in gene expression (B), protein levels of $\beta$-adrenoceptors $(\mathbf{C})$ and binding to muscarinic receptors (D) in the right cardiac ventricles of rats exposed to a single $(1 \times \mathrm{IMMO})$ or repeated $(7 \times \mathrm{IMMO})$ immobilization stress. Results are presented as means \pm S.E.M of $5-10$ animals. ${ }^{\star} p<0.05,{ }^{* *} p<0.01$ and ${ }^{* * *} p<0.001$ compared to control group; $^{\# \# \#} p<0.001$ compared to $1 \times$ IMMO. $\beta$-AR, $\beta$-adrenoceptors. 
Effect of single and repeated immobilization on muscarinic receptor binding sites

In order to ascertain how stress disrupts equilibrium between $\beta$-AR (stimulators of adenylyl cyclase), and muscarinic receptors (MR; main cardiac receptors inhibiting adenylyl cyclase), we measured the number of MR in cardiac ventricles. No differences in receptor number between control and stressed animals were observed in right ventricles (Fig. 1D).

Correlation between catecholamine levels, adrenoceptor $m R N A$, proteins and $M R$ binding

There was variance in the stress effects on left and right ventricles (see Fig. 2). While in left ventricles the adrena- line levels correlated with $\beta_{2}$-AR mRNA, $\beta_{2}$-AR protein and $\beta_{3}-A R$ mRNA, in right ventricles we were able to find correlation between adrenaline and $\beta_{2}$-AR mRNA and protein only. All other variables were not dependent. It can be deduced from Figure 2 that $\beta_{2}$-AR mRNA correlated negatively with adrenaline levels in left ventricles. This correlation (adrenaline- $\beta_{2}$-AR mRNA), however, is stronger in left ventricles $(\mathrm{r}=-0.7156, p<0.001)$ than in right ventricles $(r=-0,4998, p<0.05)$. Similarly, left ventricles $\beta_{2}$-AR protein also revealed negative correlation with adrenaline levels. On the other hand, $\beta_{3}-A R$ mRNA correlated positively with adrenaline levels in left ventricles. Likewise in left ventricles, $\beta_{2}$-AR protein and mRNA in right ventricles also correlated negatively to adrenaline levels.

\section{Left ventricles}

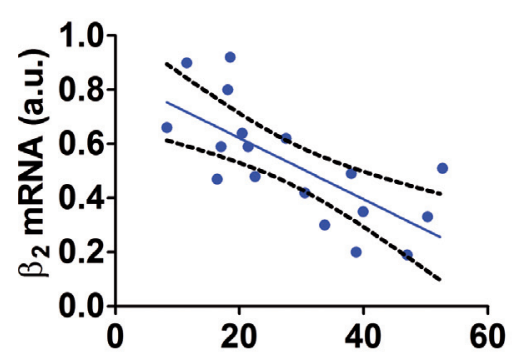

\section{Right ventricles}

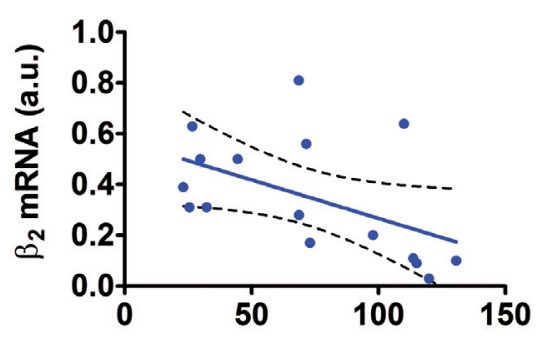

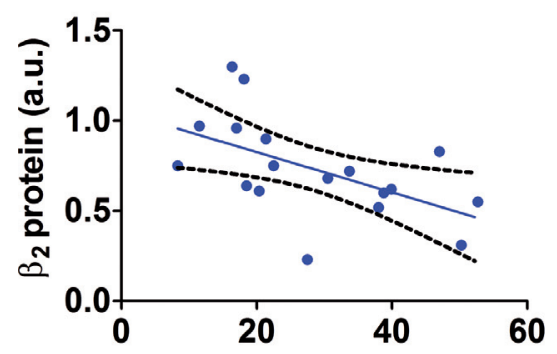

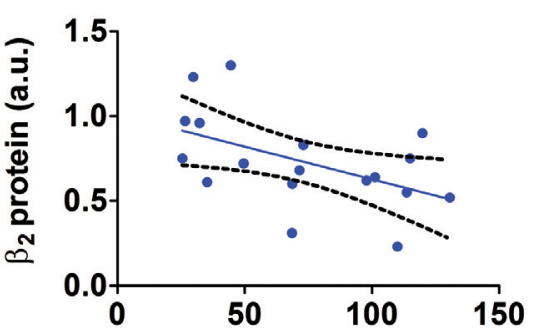

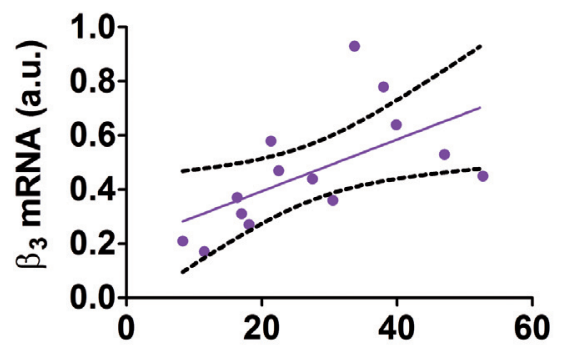

Adrenaline (ng/g tissue)

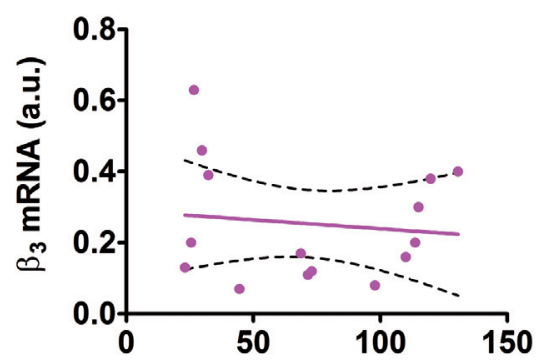

Adrenaline (ng/g tissue)
Figure 2. Correlation between adrenaline levels (expressed as ng/g tissue) and $\beta_{2}$-AR mRNA (a.u.), $\beta_{2}$-AR protein (a.u.), and $\beta_{3}$-AR mRNA (a.u.) in left ventricles (left panel) and right ventricles (right panel). The correlation was significant in all case except $\beta_{3}$-AR mRNA $v$ s. adrenaline in right ventricles. $p<$ 0.001 in left ventricles, $\beta_{2}$-AR mRNA vs. adrenaline; $p<0.05$ in all other cases. a.u., arbitrary units. 


\section{Discussion}

Our results have shown that immobilization stress (acute or repeated) increased adrenaline and noradrenaline concentration in right ventricles. These results are in good agreement with previous observations (Kvetnansky and Torda 1985). Increased adrenaline levels in ventricles are consequence of stress-induced uptake from circulation or of increased endogenous adrenaline synthesis directly in the heart (Axelrod 1962; Krizanova et al. 2001). These data show specific elevation of catecholamines in the heart chamber and allow correlating these changes with changed protein and gene expression, as shown in Fig. 2, where local catecholamine levels, $\beta$-AR subtypes gene expressions and protein levels are compared. There were less pronounced changes in the right ventricles compared to the left ventricles, which revealed broad changes (Laukova et al. 2013). More specifically, in the right ventricles, a decrease of $\beta_{2}$-AR gene expression (together with increase in $\beta_{3}$-AR gene expression) was observed after repeated immobilization. Moreover, MR changes occurred in left ventricles only (Laukova et al. 2013). The main MR subtype is $\mathrm{M}_{2}$ and we can therefore conclude that these changes occur therefore mainly for $\mathrm{M}_{2} \mathrm{MR}$.

It is generally accepted that in the failing human heart, $\beta_{1}$-AR are decreased, $\beta_{2}$-AR may or may not be decreased but are uncoupled from the effector system adenylyl cyclase (Brodde 1991; Brodde and Leineweber 2004). Our results, in contrast, showed unchanged $\beta_{1}$-AR and decreased $\beta_{2}$-AR during immobilization stress. In experiments with animals exposed to a long-term cold stress $\left(28\right.$ days at $\left.4^{\circ} \mathrm{C}\right)$ we did not find any changes in $\beta_{1}$-AR gene expression as well (Tillinger et al. 2008), in spite of huge activation of sympathoneural system and elevation of circulating noradrenaline levels. These findings could be related to the higher resistance of $\beta_{1}$-AR to agonist-induced down-regulation (Liang et al. 2003).

Stress-induced changes of cardiac $\beta_{1}$-AR and $\beta_{2}$-AR were first described in 80's (U'Prichard and Kvetnansky 1980; Torda et al. 1981, 1985). Further, the effetcs of foot-shock stress on $\beta_{2}$-AR were studied in SHR and WKY rats (Kirby and Johnson $1990)$ and $\beta_{2}$-AR were shown to be activated during acute stress in SHR but not in WKY. Another authors (Bassani and Bassani 1993) reported the down-regulation of the pacemaker $\beta_{1}$-AR but not the increased participation of $\beta_{2}$-AR in the response of the rat sinoatrial node to catecholamines after repeated footshock. Also, different stress types, like neonatal stress, restriction stress or restricted food intake induced a decrease in the density of binding sites or down-regulation of $\beta$-AR (Gudbjarnason and Benediktsdottir 1996). Another study tried to simulate oxidative stress condition in ischemia-reperfusion model and showed that $\mathrm{H}_{2} \mathrm{O}_{2}$ may depress the $\beta_{1}-\mathrm{AR}, \mathrm{G}_{\mathrm{s}}$ proteins and catalytic subunit of $\mathrm{AC}$ and thus may play an important role in attenuating the $\beta$-AR linked signal transduction due to ischemia-reperfusion injury (Persad et al. 1998). Important differences were shown between oestrus phase after inescapable foot-shock stress (Spadari-Bratfisch et al. 1999). Moreover, the stress-induced response was shown to be mediated by the $\beta_{2}$-AR subtype. In another paper of this group (Santos and Spadari-Bratfisch 2001), the chronotropic effect of (+/-)-CGP12177 were studied and it was shown that are mediated by $\beta_{1 L^{-}} A R$. In constrast with $\beta_{1^{-}}$ $\mathrm{AR}$ and (or) $\beta_{2}-\mathrm{AR}$, these receptors were resistant to the effects of foot-shock stress. In general, the effects of stress on heart $\beta_{1^{-}}$ $\mathrm{AR}$ and $\beta_{2}$-AR receptors differ (Santos and Spadari-Bratfisch 2006). Restraint stress (acute, 1 hour) did not changed $\beta_{1}$-AR or $\beta_{2}$-AR (Penna et al. 2007) while acute immobilization for 120 minutes changed $\beta_{2}$-AR (Myslivecek et al. 2004, 2008). Cold stress induced decrease of $\beta_{1}-A R$ and $\beta_{2}$-AR and increased the number of $\beta_{3}$-AR (Benes et al. 2012).

Considering the effects of stress, it is also necessary to consider the regulatory role of CNS (Fortaleza et al. 2012a, 2012b).

\section{Correlation between catecholamine levels and receptor gene expression and protein}

Our results showed variance in the stress effects on left and right ventricles. Adrenaline, but not noradrenaline levels correlate negatively with $\beta_{2}$-AR mRNA and protein both in left and right ventricles (Fig. 2). That means while the adrenaline level increases the amount of $\mathrm{mRNA}$ and protein decreases. This correlation (adrenaline- $\beta_{2}$-AR mRNA), however, is stronger in left ventricles than in right ventricles. That means that the decrease in $\beta_{2}$-AR mRNA is more susceptible to changes in left ventricles than in right ventricles. On the other hand, the protein was similarly decreased as a result of increased adrenaline levels in both left and right ventricles. Moreover, $\beta_{3}$-AR mRNA correlated positively with adrenaline levels in left ventricles but not in right ventricles showing that balance between $\beta$-AR receptor subtypes is more important in left than in right ventricles.

A balance of receptor functions achieves needed homeostasis in the heart. Our results have shown that a single and repeated immobilization stress causes complex changes in receptor proteins or binding in left ventricles (Laukova et al. 2013) but present results show only modest changes in right ventricles. On the other hand, $\beta_{2}$-AR mRNA and protein correlates with adrenaline level in both ventricles.

Taken together, decrease of cardio-stimulating $\beta_{2}$-AR represents a new important mechanism by which $\beta_{2}$-AR contributes to the heart physiology.

Acknowledgement. This work was supported by the The Ministry of Education, Youth and Sports - Institutional Support for Longterm Development of Research Organizations - Charles University, $1^{\text {st }}$ Faculty of Medicine, PRVOUK P26 - Neuropsychiatric aspects of neurodegenerative diseases, the Slovak Research and Development Agency (grant APVV-0088-10) and grant VEGA 2/0036/11. 


\section{References}

Arch J. R., Wilson S. (1996): Beta 3-adrenoceptors and the regulation of metabolism in adipose tissues. Biochem. Soc. Trans. 24, 412-418

Axelrod J. (1962): Purification and properties of phenylethanolamineN-methyl transferase. J. Biol. Chem. 237, 1657-1660

Barbier J., Rannou-Bekono F., Marchais J., Berthon P. M., Delamarche P., Carre F. (2004): Effect of training on beta1 beta2 beta3 adrenergic and M2 muscarinic receptors in rat heart. Med. Sci. Sports. Exerc. 36, 949-954 http://dx.doi.org/10.1249/01.MSS.0000128143.93407.39

Bassani R. A., Bassani J. W. (1993): Effects of escapable and inescapable foot-shock on rat atrial beta-adrenoceptors. Pharmacol. Biochem. Behav. 44, 869-875 http://dx.doi.org/10.1016/0091-3057(93)90019-P

Benes J., Novakova M., Rotkova J., Farar V., Kvetnansky R., Riljak V., Myslivecek J. (2012): Beta3 adrenoceptors substitute the role of M2 muscarinic receptor in coping with cold stress in the heart: Evidence from M2KO mice. Cell. Mol. Neurobiol. 32, 589-869 http://dx.doi.org/10.1007/s10571-011-9781-3

Bernstein D., Fajardo G., Zhao M. (2011): The role of beta-adrenergic receptors in heart failure: differential regulation of cardiotoxicity and cardioprotection. Prog. Pediatr. Cardiol. 31, 35-38 http://dx.doi.org/10.1016/j.ppedcard.2010.11.007

Bradford M. M. (1976): A rapid and sensitive method for the quantitation of microgram quantities of protein utilizing the principle of protein-dye binding. Anal. Biochem. 72, 248-254 http://dx.doi.org/10.1016/0003-2697(76)90527-3

Brixius K., Bloch W., Pott C., Napp A., Krahwinkel A., Ziskoven C., Koriller M., Mehlhorn U., Hescheler J., Fleischmann B., Schwinger R. H. (2004): Mechanisms of beta 3-adrenoceptorinduced eNOS activation in right atrial and left ventricular human myocardium. Br. J. Pharmacol. 143, 1014-1022 http://dx.doi.org/10.1038/sj.bjp.0705983

Brodde O. E. (1991): Beta 1- and beta 2-adrenoceptors in the human heart: properties, function, and alterations in chronic heart failure. Pharmacol. Rev. 43, 203-242

Brodde O. E., Michel M. C. (1999): Adrenergic and muscarinic receptors in the human heart. Pharmacol. Rev. 51, 651-690

Brodde O. E., Leineweber K. (2004): Autonomic receptor systems in the failing and aging human heart: similarities and differences. Eur. J. Pharmacol. 500, 167-176 http://dx.doi.org/10.1016/j.ejphar.2004.07.022

Brodde O. E., Bruck H., Leineweber K. (2006): Cardiac adrenoceptors: physiological and pathophysiological relevance. J. Pharmacol. Sci. 100, 323-337 http://dx.doi.org/10.1254/jphs.CRJ06001X

Burnstock G. (2009): Autonomic Neurotransmission: 60 Years Since Sir Henry Dale. Ann. Rev. Pharmacol. Toxicol. 49, 1-30 http://dx.doi.org/10.1146/annurev.pharmtox.052808.102215

Communal C., Singh K., Sawyer D. B., Colucci W. S. (1999): Opposing effects of beta(1)- and beta(2)-adrenergic receptors on cardiac myocyte apoptosis : role of a pertussis toxin-sensitive G protein. Circulation 100, 2210-2212 http://dx.doi.org/10.1161/01.CIR.100.22.2210

Fischer V., Gabauer I., Tillinger A., Novakova M., Pechan I., Krizanova O., Kvetnansky R., Myslivecek J. (2008): Heart adreno- ceptor gene expression and binding sites in the human failing heart. Ann. N. Y. Acad. Sci. 1148, 400-408 http://dx.doi.org/10.1196/annals.1410.013

Fortaleza E. A. T., Scopinho A. A., Corrêa F. M. A. (2012a): $\beta$ Adrenoceptors in the medial amygdaloid nucleus modulate the tachycardiac response to restraint stress in rats. Neuroscience 227, 170-179

http://dx.doi.org/10.1016/j.neuroscience.2012.09.048

Fortaleza E. A. T., Scopinho A. A., de Aguiar Corrêa F. M. (2012b): $\alpha 1$ and $\alpha 2$-adrenoceptors in the medial amygdaloid nucleus modulate differently the cardiovascular responses to restraint stress in rats. Pharmacol. Res. 66, 154-162

http://dx.doi.org/10.1016/j.phrs.2012.04.004

Garofolo M. C., Seidler F. J., Auman J. T., Slotkin T. A. (2002): beta-Adrenergic modulation of muscarinic cholinergic receptor expression and function in developing heart. Am. J. Physiol. Regul. Integr. Comp. Physiol. 282, R1356-1363

Gauthier C., Leblais V., Kobzik L., Trochu J.N., Khandoudi N., Bril A., Balligand J. L., Le Marec H. (1998): The negative inotropic effect of beta3-adrenoceptor stimulation is mediated by activation of a nitric oxide synthase pathway in human ventricle. J. Clin. Invest. 1998, 1377-1384 http://dx.doi.org/10.1172/JCI2191

Gauthier C., Tavernier G., Trochu J. N., Leblais V., Laurent K., Langin D., Escande D., Le Marec H. (1999): Interspecies differences in the cardiac negative inotropic effects of beta(3)adrenoceptor agonists. J. Pharmacol. Exp. Ther. 290, 687-693

Gauthier C., Langin D., Balligand J.-L. (2000): b3-adrenoceptors in the cardiovascular system. Trends Pharmacol. Sci. 21, 426-431 http://dx.doi.org/10.1016/S0165-6147(00)01562-5

Gomeza J., Shannon H., Kostenis E., Felder C., Zhang L., Brodkin J., Grinberg A., Sheng H., Wess J. (1999): Pronounced pharmacologic deficits in M2 muscarinic acetylcholine receptor knockout mice. Proc. Natl. Acad. Sci. U.S.A. 96, 1692-1697 http://dx.doi.org/10.1073/pnas.96.4.1692

Gudbjarnason S., Benediktsdottir V. E. (1996): Regulation of betaadrenoceptor properties and the lipid milieu in heart muscle membranes during stress. Mol. Cell. Biochem. 163-164, 137-143 http://dx.doi.org/10.1007/BF00408650

Kaumann A. J., Molenaar P. (2008): The low-affinity site of the $\beta 1$ adrenoceptor and its relevance to cardiovascular pharmacology. Pharmacol. Therapeut. 118, 303-336 http://dx.doi.org/10.1016/j.pharmthera.2008.03.009

Kirby R. F., Johnson A. K. (1990): Role of beta 2-adrenoceptors in cardiovascular response of rats to acute stressors. Am. J. Physiol. 258, H683-688

Krizanova O., Micutkova L., Jelokova J., Filipenko M., Sabban E., Kvetnansky R. (2001): Existence of cardiac PNMT mRNA in adult rats: elevation by stress in a glucocorticoid-dependent manner. Am. J. Physiol. Heart. Circ. Physiol. 281, H1372-1379

Kvetnansky R., Mikulaj L. (1970): Adrenal and urinary catecholamines in rats during adaptation to repeated immobilization stress. Endocrinology 87, 738-743 http://dx.doi.org/10.1210/endo-87-4-738

Kvetnansky R., Torda T. (1985). Pathogenesis of Stress-induced Heart Disease. (Eds. R. E. Beamish, V. Panagia, N. S. Dhalla), pp. 3-19, Boston-Dordrecht-Lancaster, Martinu Nijhoff Publishing Group a member of the Kluwer Academic Publishers Group 
Laukova M., Tillinger A., Novakova M., Krizanova O., Kvetnansky R., Myslivecek J. (2013): Repeated immobilization stress increases expression of $\beta 3$-adrenoceptor in the left ventricle and atrium of the rat heart. Stress Health (in press) http://dx.doi.org/10.1002/smi.2515

Liang W., Austin S., Hoang Q., Fishman P. H. (2003): Resistance of the human beta 1-adrenergic receptor to agonist-mediated down-regulation. Role of the $\mathrm{C}$ terminus in determining betasubtype degradation. J. Biol. Chem. 278, 39773-39781 http://dx.doi.org/10.1074/jbc.M304482200

Molenaar P., Sarsero D., Kaumann A. J. (1997): Proposal for the interaction of non-conventional partial agonists and catecholamines with the putative beta 4 -adrenoceptor' in mammalian heart. Clin. Exp. Pharmacol. Physiol. 24, 647-656 http://dx.doi.org/10.1111/j.1440-1681.1997.tb02107.x

Myslivecek J., Trojan S., Tucek S. (1996): Biphasic changes in the density of muscarinic and beta-adrenergic receptors in cardiac atria of rats treated with diisopropylfluorophosphate. Life Sci. 58, 2423-2430 http://dx.doi.org/10.1016/0024-3205(96)00246-9

Myslivecek J., Ricny J., Palkovits M., Kvetnansky R. (2004): The effects of short-term immobilization stress on muscarinic receptors, beta-adrenoceptors, and adenylyl cyclase in different heart regions. Ann. N. Y. Acad. Sci. 1018, 315-322 http://dx.doi.org/10.1196/annals.1296.038

Myslivecek J., Novakova M., Palkovits M., Krizanova O., Kvetnansky R. (2006): Distribution of mRNA and binding sites of adrenoceptors and muscarinic receptors in the rat heart. Life Sci. 79, 112-120 http://dx.doi.org/10.1016/j.lfs.2005.12.026

Myslivecek J., Tillinger A., Novakova M., Kvetňanský R. (2008): Regulation of adrenoceptor and muscarinic receptor gene expression after single and repeated stress. Ann. N. Y. Acad. Sci. 1148, 367-376 http://dx.doi.org/10.1196/annals.1410.028

Nantel F., Bonin H., Emorine L. J., Zilberfarb V., Strosberg A. D., Bouvier M., Marullo S. (1993): The human beta 3-adrenergic receptor is resistant to short term agonist-promoted desensitization. Mol. Pharmacol. 43, 548-555

Penna C., Abbadessa G., Mancardi D., Spaccamiglio A., Racca S., Pagliaro P. (2007): Nandrolone-pretreatment enhances cardiac $\beta 2$-adrenoceptor expression and reverses heart contractile down-regulation in the post-stress period of acute-stressed rats. J. Steroid Biochem. Mol. Biol. 107, 106-113 http://dx.doi.org/10.1016/j.jsbmb.2007.05.005

Persad S., Panagia V., Dhalla N. S. (1998): Role of H2O2 in changing beta-adrenoceptor and adenylyl cyclase in ischemia-reperfused hearts. Mol. Cell. Biochem. 186, 99-106 http://dx.doi.org/10.1023/A:1006823531286

Peuler J. D., Johnson G. A. (1977): Simultaneous single isotope radioenzymatic assay of plasma norepinephrine, epinephrine and dopamine. Life Sci. 21, 625-636 http://dx.doi.org/10.1016/0024-3205(77)90070-4

Rozec B., Gauthier C. (2006): [beta]3-Adrenoceptors in the cardiovascular system: Putative roles in human pathologies. Pharmacol. Ther. 111, 652-673 http://dx.doi.org/10.1016/j.pharmthera.2005.12.002

Santos I. N., Spadari-Bratfisch R. C. (2001): Chronotropic response to (+/-)-CGP12177 in right atria of stressed rats. Can. J. Physiol. Pharmacol. 79, 393-399 http://dx.doi.org/10.1139/y01-007

Santos I. N., Spadari-Bratfisch R. C. (2006): Stress and cardiac beta adrenoceptors. Stress $\mathbf{9}, 69-84$ http://dx.doi.org/10.1080/10253890600771858

Schulz R., Rassaf T., Massion P. B., Kelm M., Balligand J. L. (2005): Recent advances in the understanding of the role of nitric oxide in cardiovascular homeostasis. Pharmacol. Ther. 108, 225-256 http://dx.doi.org/10.1016/j.pharmthera.2005.04.005

Skeberdis V. A., Gendviliene V., Zablockaite D., Treinys R., Macianskiene R., Bogdelis A., Jurevicius J., Fischmeister R. (2008): $\beta 3$-adrenergic receptor activation increases human atrial tissue contractility and stimulates the L-type Ca2+ current. J. Clin. Invest. 118, 3219-3227

Spadari-Bratfisch R. C., Santos I. N., Vanderlei L. C., Marcondes F. K. (1999): Pharmacological evidence for beta2-adrenoceptor in right atria from stressed female rats. Can. J. Physiol. Pharmacol. 77, 432-440 http://dx.doi.org/10.1139/y99-031

Spasojevic N., Gavrilovic L., Dronjak S. (2011): Regulation of atrial catecholamine enzymes and adrenoceptor gene expression after chronic stress. Acta Physiol. Hung. 98, 433-441 http://dx.doi.org/10.1556/APhysiol.98.2011.4.6

Stavrakis S., Kem D. C., Patterson E., Lozano P., Huang S., Szabo B., Cunningham M. W., Lazzara R., Yu X. (2011): Opposing cardiac effects of autoantibody activation of beta-adrenergic and M2 muscarinic receptors in cardiac-related diseases. Internat. J. Cardiol. 148, 331-336 http://dx.doi.org/10.1016/j.ijcard.2009.11.025

Tavernier G., Toumaniantz G., Erfanian M., Heymann M. F., Laurent K., Langin D., Gauthier C. (2003): Beta3-Adrenergic stimulation produces a decrease of cardiac contractility ex vivo in mice overexpressing the human beta3-adrenergic receptor. Cardiovasc. Res. 59, 288-296 http://dx.doi.org/10.1016/S0008-6363(03)00359-6

Tillinger A., Myslivecek J., Novakova M., Krizanova O., Kvetnansky R. (2008): Gene expression of adrenoceptors in the hearts of cold-acclimated rats exposed to a novel stressor. Ann. N.Y. Acad. Sci. 1148, 393-399 http://dx.doi.org/10.1196/annals.1410.024

Torda T., Yamaguchi I., Hirata F., Kopin I. J., Axelrod J. (1981): Quinacrine-blocked desensitization of adrenoceptors after immobilization stress or repeated injection of isoproterenol in rats. J. Pharmacol. Exp. Ther. 216, 334-338

Torda T., Kvetnansky R., Petrikova M. (1985): Effect of repeated immobilization stress on central and peripheral adrenoceptors in rats. Endocrinol. Exp. 19, 157-163

U'Prichard D. C., Kvetnansky R. (1980): Catecholamines and Stress: Recent Advances. (Eds. E. Usdin, R. Kvetnansky, I. J. Kopin), pp. 299-308, New York, Elsevier

Xiao R. P., Zhu W., Zheng M., Cao C., Zhang Y., Lakatta E. G., Han Q. (2006): Subtype-specific alpha1- and beta-adrenoceptor signaling in the heart. Trends Pharmacol. Sci. 27, $330-337$ http://dx.doi.org/10.1016/j.tips.2006.04.009

Received: August 21, 2013

Final version accepted: January 2, 2014 